\title{
The identity of the political language, compared to other types of language
}

\author{
Mihaela Mocanu \\ Human Science Research Department, \\ "Alexandru Ioan Cuza" University, Romania \\ 11 Carol I Boulevard, RO 700506 - laşi \\ mocanu.mihaela@uaic.ro
}

\begin{abstract}
The existence of a political language implies recognising a stability of the linguistic code, outside the concrete situations of communication. Anyone who listens to the speech of a politician ascertains that he uses particular wording and phrases, manifests fondness for specific topics, makes appeal to a specific rhetoric, employs an adequate intonation, all aimed at facilitating the achievement of his objectives. The audience recognises immediately this type of language, which means that the political language has a distinctive identity, at the level of the content and of the expression as well, compared to the other types of language, even if, often, it valorises the contents and the expressions specific to these languages. In our study, we present a contrastive analysis of the political language, compared to other types of language (scientific, philosophical, religious, legal, artistic), aimed at identifying the defining notes, but also the convergence area that exist among them.
\end{abstract}

Keywords: political language, language taxonomies, contrastive analysis

\section{INTRODUCTION}

The expression of the force balance on the political scene is created by approaching a range of extremely varied languages: image, music, objects, uniforms, architecture, symbols etc. Almost all products of the human activity or which have a connection to the human activity can be taken and valorised by the political action, but the verbal language has priority, by its impact upon the audience, but also by its' multitude of appearances. To that end, M. Edelman claims that "language is an integral facet of the political stage: not only an instrument for describing the events, it is itself a part of the events, strongly emphasizing their significance and helping the defining of the political parts that the authorities and the masses consider they play"(Edelman 1999: 3). In other words, the political language becomes the equivalent of the political reality.

In our study, we assimilate the language to a "linguistic system, more or less specialised in expressing the content of ideas that is specific to a professional activity, to one or several domains in the social - cultural life (...) all having (or aiming at having) specific words, phrases and organising rules, resulting from different restrictions imposed to the language" (Coteanu 1975: 45). From this perspective, language would be an idiom to which on attach a special destination and which is characterised by specific discursive mechanisms. Assuming the political language as object of analysis imposes a few definitions regarding the 
conceptual sphere of the political epithet and in emphasizing the criteria that assign the political feature to a language.

In the course of the contrastive analysis, we start from the premises that the individuality of the political language, compared to the other types of languages, is conferred by the approached contents but also by the expression means used, due to the fact that politics attaches particular meanings to the words from the common vocabulary, and the enouncing of the political ideas and concepts is done by using individual syntactical structures. Also, shaped by specific discursive goals, the political language is distinguished by an emphasized pragmatic dimension, being similar, in that sense, to the advertising language.

\section{LANGUAGE TAXONOMIES}

According to the domains in which they are used, we discern a variety of languages: scientific, philosophical, religious, legal, poetic etc., each of them being defined by specific features, both at the level of the contents expressed, as well as at the level of expression and of the aimed effects. The discrimination and the description of the types of languages is not limited to the ensemble of the linguistic specificities (phonetic, morphological, syntactical, lexical) being forced to make appeal to extra-linguistic data from the domain in which they are used. Both linguistic and extra-linguistic factors compete for configuring some distinctive profiles, each type of language being usually characterized by approaching three elements of reference: the context criterion, the emitter criterion and the contents criterion.

Understanding the language as logos semantikos, conception that postulates the absolute of the signification function/goal compared to the potential determinations subsequent to the speech (to the language in use), Aristotel distinguished three discursive goals: apofantic finality (scientific or reasonable, materialized into the true/false relation), the pragmatic finality (practical, determined by the values of practical efficacy) and poetic finality ${ }^{1}$. All these three goals are perceived as ulterior determinations and not as constituents of the language as free and unintended expression of certain contents of the human conscience. They are related to the intentions and the attitudes expressed by the speaker, reflecting as many clues for orienting the construction of significance in one of the three directions. From this perspective, the scientific language is characterised by apofantic finality, the legal and didactical by pragmatic finality and the artistic language is, in essence, the manifestation place for poetic finalities. The political language has a pragmatic finality par excellence, aiming at prevailing on the receptor, at modifying his/her attitude, and the specificity of this type of language is conferred by the parameters of the communication situation: protagonists/ communication roles, space, time, goals, expression means.

Besides the domain in which they are spread, the languages are differentiated by:

- The monosemic and polisemic character (there are in principle two ways of constituting the global significance: a monosemic one, when the delimitation and the game of the semantic fields lead to a unique, well determined significance, and a polisemic one, when the significations reached are plural, ambiguous).

-Referentiality - is a function of language oriented towards the context, towards the extradiscursive, and represents an extension of the designation that we meet at the sign level. At the opposite pole, the self-referential or poetic function expresses the tendency of the speech to send towards itself and not to something external.

\footnotetext{
${ }^{1}$ The three hypostasis of logos semantikos are described by Aristotel in Poetica (poetical logos),About interpretation (apofantic logos) and Retorica (pragmatic logos).
} 
The monosemie, through the manner in which it works, seems to be correlated to the referentiality of the speech, while the polisemie, the ambiguity of the global significance and the plurality of meanings is correlated to the self-referentiality of the speech (Codoban 2005: 56-57). Referring to the two sides, of the meaning and of the referentiality, we can characterise and classify the cultural discursive manifestations. Thus, the scientific language is defined by referentiality and the monosemie, while the poetic language, at the opposite pole, is distinguished by cultivating the self-referentiality and the polisemie. The philosophical language has a particular statute: it is not characterised by the rigorous monosemie of the scientific language, neither can reach the polisemie of the artistic speech; does not register the level of referentiality of the scientific language, but is more referential than the poetic language, even if this referentiality aims the world as a unit.

\section{CRITERIA FOR DELIMITATING THE POLITICAL LANGUAGE}

Due to the variety of manifestation forms of the political language and to their eclecticism, it is difficult to identify criteria that could allow their inclusion into the same species. The attempt of distinguishing an internal principle for classifying the discursive manifestations in political and non-political can seem redundant, under the conditions in which, a simple word could have political effects, according to the context in which it is produced by the emitter. Under these conditions, it is mandatory to identify external parameters for encompassing political languages such as: the effects aimed by communication (changing the political order, legitimation of a political act, causing the political adhesion of the audience etc.) or the emitter's statute (politician, journalist, analyst etc.).

Which are the features that confer the political character to a language or to a speech and how can we identify these features? For this purpose, Jean-Marie Denquin suggests three identification criteria (Denquin 2007: 21):

a) The emitter's criterion: the speech of a politician is political. This criterion is not entirely valid, since we cannot limit the usage of the political speech exclusively to the people who are active on the political stage: the discussion between two persons who are not engaged into the political sphere may also have a political character.

b) The content criterion: seems to raise less inconvenient compared to the first one, under the conditions in which not all words used by a politician belong to the political vocabulary. The topic, the theme will cause the political character of a language and not the nature of the words used. "Any political language uses a political speech, but the converse is not valid" (ibidem).

c) The context criterion: there are situations in which the political actors express political speeches, other times their statute confer them a political character to a content that has nothing to do with politics (for instance a technical or economical argumentation).

The political character of a language is determined by the communication situation in which it appears and not by the approached contents. From this perspective, Patrick Charaudeau distinguishes three hypostasis in which the political languages can be used (Charaudeau 2005: 30):

- the political language as system of thinking;

- the political language as communication act;

- the political language as comment of the political referential. 
The epithet political has, according to Jean-Marie Denquin, the role of opposing a type of language to other languages, and in the case of the discursive manifestations that have no political character by the vocabulary used, by the topic or the rhetoric involved, the qualification is done by referring to the context. Thus, a politician who shouts "What a horror!" when with his family, does not use a political speech, but in front of a camera, referring to an assault, this sentence gets a political character.

The political language is, in essence, the language specific to the political communication, mean of expressing the events of the political stage and of the political preferences of the speaker, space for reconstructing the political referential, from the perspective of the political interests of the emitter, support of the ideology, of the values and beliefs, instrument of manipulation, by instilling new attitudes and values to the audience. The political language does not represent an adornment, an over-structure, but it is a part of the political action, to the extent in which the political representations, through which the persons and the groups define themselves, gain consistence and visibility by the discursive manifestations. Numerous political acts are, by their nature, speech acts (an example in this way is represented by the resignations), and others support themselves in their expression by words. By the specific features of the political language, the bibliographic references mention the inter-discursive nature, the dramatization, the legitimation finalities, the intentionality, the persuasion stake and the ideological content.

\section{THE IDENTITY OF THE POLITICAL LANGUAGE, COMPARED TO OTHER TYPES OF LANGUAGE}

The autonomization of a political language with specific identity is done in the middle of the $22^{\text {nd }}$ century, along with the intuition of the importance of the logos in the configuration of the force balance on the political stage. The political language is distinguished from the other types of language by the topics approached, by the organisation ways and by the inventiveness of the proceedings used in starting and amplifying the audience's state of mind. By the features that confer specificity to the political speech, Constantin Sălăvăstru notes: the intentional ambiguity, aimed at influencing a wider category of receptors; the dissimulated character of the message, given the fact that there is never a perfect correlation between the intentions of the speaker and what he says and does, some things remaining permanently hidden to the receptor; the imperative tonality, aiming at causing a reaction from the audience, in the way of legitimating the power group represented by the emitter; the explicit polemic substrate of the political speech, which translates the emitter's interests and aspirations, confronting them in the same time with the ones of the political opponent (Sălăvăstru 2009: 76-94).

Performed among a series of freedoms and constraints established, on one hand, by the goal aimed, on the other hand, by the features of the parameters of the communication situation, the discursive manifestation from the political space gains a particular physiognomy also by the specificity of its functions. Addressing to a vast and heterogeneous audience, the political language is characterised by an increased degree of accessibility at the level of the contents spread at the level of the verbal expression as well. Thus, "a balance is required between the scientific or legal accuracy and the ambiguity of the current language, of the common language, as between solemnity and familiarity" (Zafiu 2007: 20). During our century, we notice the evolution of the political language towards the informal, towards the conversational, towards the excessive simplification, specific elements for the populist speech. The tendency towards stereotypy, towards the intensive usage of the fixe, preset expressions, towards adopting reiterative syntactic structures, the assumption and proliferation 
of some preferred symbols and metaphors are features that transform the political language into a type of artefacts capable of serving the politician's interests and that requires from the audience only the updating of significances that the discursive practice relates to these signs. The usage of rhetoric means and the preference for the word with high affective substance ensures an increased impact at the level of the receptor, and the use of political myths facilitates the adjunction of an evaluative dimension. In close relation to the tendency of manipulation characterising the political language, the euphemism aims at protecting the interlocutor, but, most of all, the self-protection of the emitter. In the context of the political language, the euphemism becomes a technique used for reconstructing the political referential, by promoting an image according to the speakers' intentions and aspirations.

In the next lines we suggest a contrastive presentation of the features of the political language, compared to other languages specific to other fields of knowledge and communication, in order to identify distinctive notes but also convergence elements existing between them.

\subsection{Political language vs. scientific language}

Expression of abstract and objective thinking, the scientific language aims at approaching the reality from a scientific perspective. While, the political language operates in the space of the opinion, the scientific language aims at adequacy to the reality and the accurate presentation of this one. Construction of a dissimulated thinking, promoting the values of the group of power, even when in flagrant conflict with the truth, the political language is fundamentally distinguished from the scientific one, performed above any group interests and involving all methods and means available for discovering the truth. The relationship of the political language with the truth is affected by a series of factors which influence the adequacy to the referential, so that in the overlay zone between what is said in the context of the political language and what is really happening becomes insignificant. Among the elements that affect the relationship of the political language with the truth we remind, on one hand, the factors related to the specificity of the political field, being in continuous change, and, on the other hand, the factors which aim the ideological character of the discursive manifestations from the political field. By promoting the values and the beliefs of a political group, the political emitter finds himself in the situation in which he must choose between the fidelity regarding the truth and the political interests. The relationship with the referent causes specific features as well: if the scientific language has the purpose of accurately representing the reality, in the political field, the mystification, the histrionic use of the language become instruments in the struggle for power. From here, the appeal to various rhetoric techniques, to stylistic adornments aimed at making the discursive manifestations more efficient, from the point of view of the aimed effects.

At lexical level, the differences between the political and the scientific vocabulary derive from the functions accomplished by the two types of language: the use of a specialized terminology, in the case of the scientific communication, is in accordance to the principle of avoiding the ambiguity (from here the denotative, univocal character, without eloquence of the scientific language); on the other hand, the principle of accessibility imposes to the political emitter the use of the common vocabulary, which does not require special understanding efforts from the side of the audience.

The differences appear also at the level of the approached topic: if in the case of the political language the emitter approaches an extremely wide thematic sphere, in the attempt of legitimating the statute, the specific of the scientific communication is the exhaustive approach of a singular theme. In the case of the political language, the topic is tributary to the pragmatic dimension, the subjects being selected based on their effects, on the attitudes that the politician intends at the receptor's level. 


\subsection{Political language vs. philosophical language}

The philosophical language is often compared to the literary language. Referring to this preference, Aurel Codoban emphasized that the philosophy was not at its origin a primary and direct interpretation of the world, as some believe, a speech regarding the world, but a cultural speech applied to another speech: the mythological literature (Codoban 2005:15). Thus, philosophy is not a speech of knowledge, but, similar to the mythological literature, is above all a signification speech. From this perspective, the philosophical language gains the character of a meta-speech, having as object the signs of another speech, and the passage from the sacred experience, evoked by the myth, to the profane, daily experience is equivalent to the shifting of the accent from a wide, unconfined the polisemie, favouring ambiguity, to a polisemie adjusted through conceptual delimitations. The autonomization of the philosophical language compared to the artistic language has as premises the reinterpretation of its own significations, of the defining problems, the reflexive approach of its own nature. Compared to the literary language, characterised by the unconfined game of significations, the philosophic language manifests the tendency of restraining it, by creating new meanings specific to the profane experience, as well as the mythological literature suggests meanings that are characteristic to the sacred experience.

„Specific to the philosophic language in general is a certain statute of numbers, of terms that it uses to operate from the perspective of their content. The process of signification represents a generalization by converting the objects and their features into conscience acts, in mental images and structures" (Oprea 2001: 224). Thus, the philosophic language is defined by the usage of abstract names, related to logical constructions that do not refer to material realities. In the case of the abstract names, the ostensive indication of the reality (the referent) is excluded, fact that favours the various interpretation of the significance. The impossibility of relating to the reference is compensated by the consistence and the coherence of the philosophical language.

The identity of the philosophical language is conferred by the approached topic: interrogating, analysing the meanings regarding the world and the man become its deep centre. The speculative character of such an approach situates the philosophical language among the discursive manifestations with the highest level of freedom. Without aiming an effective pragmatic component, the philosophical language starts from reflections regarding the social order, and ends with suggesting some alternatives for it. In this point, the similarity to the political language is obvious, in the measure in which the philosopher and the politician are, in a big way, the founders of a world. But, in the political area, the new world is shaped according to the ideological values that the speaker shares, while in the context of the philosophical speech, the conflict appears only at the level of ideas: "Regardless of the nature of the philosophical speech, being either justificatory (demonstrative - argumentative), or constructive (speculative - abstract), it aims at bringing in front of the receptor a new "order of the world", either a real order of the world, that it justifies and founds, or a possible order of the world, that it builds. The order of the world has too few contacts with the group interests in order to be able to determine the ideological character of such a speech." (Sălăvăstru 2009: 64).

By analysing the specificity of the philosophical language, Ludwig Wittgenstein underlines that, unlike other types of language, this has nothing to explain, but only to describe (Wittgenstein 1993: 53-54). While the political language has the task of developing, of justifying the political acts, the philosophical language is reflexively referring to being. Philosophy is not the knowledge of reality (as science); the role of philosophy is not to offer pictures of the world, nor to explain the world mysteries. Wittgenstein's doubts are not aimed at explaining the real facts and phenomena, but only the conceptual classification, contributing to the complete understanding of some controversial subjects. From this 
perspective, the differences between the philosophical language and the political language are emphasized and force to distinctive approach of the discursive manifestations specific to the two fields of knowledge.

$\mathrm{H}$. Wald stresses that "although there is a specific language of the philosophy, there still is a particularity of the philosophic language" (Wald 1983: 53), in the way that the philosopher uses the common language, but it uses it in an unusual manner by conferring it a special, original purpose: metasemic and metaphoric, categorical and expressive. Consequently, the individuality of the philosophical language is not conferred by the usage of a professional terminology, and by the particular use of words: "aiming the universal, the philosophical language is richer in nouns than in verbs, in nominative than in genitive, in attributive sentences than in relational sentences; the verb TO BE is more often met in its copulative sense, aiming the essence, than under the form of the present indicative, aiming the existence" (ibidem).

Another important difference between the two types of language aims the pragmatic dimension: the political language is characterised by the practical functionality, being a way for following the conquest/maintenance of power, while the philosophical language has purely theoretical reasons. Emphasizing the responsibility that the word has in the political field, Constantin Sălăvăstru claims that ,metaphorically speaking, due to the philosophical speech, destinies were crushed, hopes were suppressed, communities have disappeared entirely!" (Sălăvăstru 2009: 21).

Having the being as object of reflection and becoming more and more aware that the being is first of all the submitted-being, philosophy offers a particular attention to language, convinced that this can offer answers to its great questions. This happens simultaneously with the linguistic tourniquet of the $60 \mathrm{~s}$ which made language the preferred subject of the century. Thus, the reflection upon the language-reality ratio, upon the path from word to language, makes appeal to language, even if the precariousness of words, the impossibility of answering all the questions using words are accepted limits in the context of the philosophical approach. The philosopher uses words in his attempt of getting beyond them because what matters is not the word, but the Being. The reflection based on his own communication instrument is not equivalent to giving up the important issues of the being, but with the attempt of developing, identifying the words and the meanings, of establishing the mechanisms that create the base of the significance.

Liiceanu notes: „The language of philosophy is not liturgical; in the dialogue of the man with the infinite, only the thinking is festive, the words remain common. We don't need other words, but other ideas in order to approach a topic from a philosophical point of view" (Liiceanu 1992: 50). Through these lines a fundamental difference is revealed between the political and the philosophical language: while the first one is the result of a long pursuit, of a selection, aiming the most appropriate word for serving the emitter's interests, the philosophical language makes appeal to common, simple words and where their power of significance proves to be faint, the silence is restored.

\subsection{Political language vs. religious language}

The identification of a language specific to the religious field implies the identification of some features that distinguish it from the other forms of discursive manifestation. Thus, Gh. Chivu claims that the specificity of the religious language is not conferred only by the terminology, but also by features like: the archaic character, the monumentality, the necessity of keeping the distance from the current speech, without losing the capacity of communication and of affective involvement; the desire of balancing the tradition with the modernity, the sacred side with the accessibility (Chivu 1997: 7). At the level of the 
vocabulary, we notice the high number of archaisms, as well as the semantic technicality of some words from the common vocabulary.

The individuality of the religious language is conferred by a series of linguistic phenomena. Thus, the extension of the symbolic principle generates the use of common nouns and of pronouns as proper names, as substitute of the divinity: Father, You, The One, He, His etc. At morphological level, another aspect refers to the definite articulation of the common nouns, these acting as real proper names (The Ghost, The Lord) (ibidem). At the level of the syntax, the religious language is distinguished by the consequent elide of the verb, by the concord of the apposition with the regent, by archaic syntactic constructions in which the dative has possessive value, by the frequency of the conjunction and, which gives a narrative character to the speech, by cultivating the inversion, by creating the symmetry. The distinctive note of the religious language remains the vocabulary. The treatises set off the presence of numerous words that are currently no longer used, the high number of lexical archaisms, of the loan words from Slavonic and Neo-Greek languages, the preservation of certain old words of Latin origin, kept only in dialect, the use of some etymological forms without prefix or of the calculi with unusual structures. Also numerous are the semantic archaisms, that imply the preservation of some significances disappeared long time ago from the literary language.

Instrument of religious knowledge and communication, the religious language is founded on the recognition of a sacred world, in reference to which the religious dimension of our being is defined. From a semantic perspective, the religious language finds its origin in a preexisting extra-linguistic referent, a referent which eludes the historical type spatial - temporal categories, in the attempt of building a world of transcendental essence and of instituting a relationship between man and sacred. In this perspective, the word plays the part of a mediator between the human being, inscribed in the world of the profane and the sacred world of the divinity. By ignoring the objective referential, the religious language is comparable to the self-reflexivity of the poetic language.

If, at a first glance, the religious language and the political language seem totally distinct, they become similar at the level of the symbolic relationships which they built. Both the political language and the religious language justify their existence by discursive mechanisms of legitimation that they activate. They both propose to the person a particular reading of the reality, through the prism of the shared ideology, in the case of the political, and from the angle of the sacred, in the case of the religious language. Similar to the politics, the religion uses discursive manifestations in order to apprise its values and to win the adhesion of the believers, without whom the institution of Church could not prove its utility. Both the religious and the political speech design values and decide their hierarchy. But, while the political language is built around values as truth, justice, equality, freedom, solidarity etc., the religious language cultivates the dichotomy good - evil, suggesting models, meanings, rules, in accordance to the Christian values.

\subsection{Political language vs. legal language}

An analysis of the legal language, as communication instrument specific to the legaladministrative field, cannot hide its pragmatic dimension. More than in the case of the other domains, in the legal field, "to talk" means "to act" and the illocutionary force and the implicit mechanisms appoint the institutional framework of the communication among people. The legal language is the favourable field for proliferating the efficient sentences, because the emitter of such a language has the authority that makes such sentences operational. In the field of the legal communication, the language becomes, from a passive instrument used for reflection (or interpretation) upon the extra-linguistic reality and, eventually, for influencing the companion, an "active" instrument for transforming the reality. 
The variety of the finalities causes the diversification of the legal language, so that we could speak about a plurality of manifestation forms of this one. "According to the way in which the right that it proposes is achieved: there is a legislative, a jurisdictional, administrative, notarial, doctrinaire language, a language of the maxima and of the adagio etc., each of them differentiating types of speech that, though similar in certain ways, can be clearly distinguished by a sum of observable features at trans-textual level" (Mastacan 2004: 55).

Similar to the scientific language from a stylistic point of view, the legal language gains its specificity through formalisation, both at the level of syntax and at the semantic level. Thus, the preference for cultivating some particular syntactic structures, the semantic specialisation of the terms, the denotative character, the clarity and concision of the style, the property of the words, the objectivity are some of the constants of this type of language. The legal language is an institutionalized language, characterised by relatively rigid enunciations and syntactic structures, and which change is a much slower rhythm than the political language, forced to permanently adapt to the realities of the time that generates it. The simplification and the specialisation of the syntactic structures follow after all the avoidance of the equivoque and of the subjective interpretation.

Like in the case of the political language, the legal language has a pronounced pragmatic component, aiming at modifying the audience's attitude, the settlement of the social behaviours, in accordance to the legal rules accepted by a historical community. The specificity of the legal language is given, on one hand, by the specialized terminology, and on the other hand by its coercive character. Less free than the political language, the legal one is characterised by a high degree of inaction concerning the linguistic and syntactic structures used. Regarding the stylistic function, the legal language bears the imprint of the interaction among the referential, meta-linguistic and willed function.

Aiming an explicative - justificatory activity for elaborating and applying the rule, considering the re-composition of some past events for the perspective of the qualification and endorsement of the ones who produce those specific events, according to the current rules, the legal language, as well as the political language, suggests a reinterpretation of the events, through the prism of the effects aimed at the level of the audience. As in the case of the political language, the pragmatic dimension shapes the syntax and the semantic of the legal language, because in these fields, the consequences can be neglected. The difference is given by the normative framework, especially the current legislation that limits and organises in the same time the discursive manifestations. If in the political field, the issue of the legitimacy is fundamental, in legal plan the individual freedom becomes a priority.

The legal language is a normative language par excellence, defining the rights and obligations unanimously accepted into a society, as well as the conditions for application of the effective legislation. Both legal and political language are prescriptive, the two discursive manifestations interfere, as far as the political power must consider the social rules in order to legitimate its existence. Both aim the description of a particular social order, but, while the shape of the political language it based on the ideological values that it spreads, the legal language presents superior ranked rules, situated above the class or individual interests. The political power adapts its speech to the legal power because ignoring it draws the obliteration of the legitimacy of the first one. The legal language has a special relationship with power, this time with the legal power, which needs the discursive manifestations in order to legitimate and to generate adequate behaviours to the receptors. From this perspective, the language contributes to the establishment of the legal power and to handling its relationships with the members of the society. 


\subsection{Political language vs. poetic language}

Specific to the artistic knowledge and communication, the poetic language elaborates its own referent, with no connexion to the extra-verbal, pre-existent world. As communication tool of the art, the language is ruled by the poetic function, which converts the linguistic communication into aesthetical communication. Singularizing by the development of some unique semantic and syntactic relations, the poetic language sets up among the constraints of the linguistic system to which it belongs and the creative impulses of the emitter. More than any other type of language, the poetic one is defined by expressivity, as result of the original vision of the artist.

Usually characterized by reference to the scientific language, considered by Roland Barthes „the zero degree of language”, the poetic language has a specific configuration compared to the other languages. Thus, if commonly, breaking the linguistic rules affects the reception of the message, in the case of the poetic language, the artist deliberately ignores the "rule", and the freedom that it manifests becomes the sign of the originality and of the creative invention. The deviations that characterize the poetic language, at the level of the verbal expression, cause significant distances between the signification given by the artist to his work and the meaning decoded by the receptor, without blocking the aesthetical emotion. The difficulties that this type of language raises are important and can be cancelled only by an effort for reconstructing the world that the creator suggests and, implicitly, of the meanings invested into the used signs. The apparent conflict state between the poetic and the common language finds its solution in the awareness of the mutation in the field of arts, in which, the process of developing the significance does not follow the usual rules, having its own structure and functioning.

In the case of the poetic language, the ratio between the expression and the context is extremely complex: the expression, the significant gains an active part in elaborating the significance, and the concept becomes a second degree significant in its turn, by the functional reorganising of the relations between expression and content. If in the case of the common language, the significance is transparent and i-mediate, in the case of the poetic language this is matt and indirect, mediate. The significance is born here from the tensions between the significant and the concept, both playing an active part in the process of signification.

A defining feature of the poetic language is reflexivity: the artistic communication implies the adaption of the language upon itself, upon the significant potential that it owns, by rediscovering the expressive valences of the language and the reinvention of the degraded word by the overbid speech. Thus, we assist to an inversion of the ratio between the functions that the language fulfils in the context of the other knowledge field: the accent shifts from the supremacy of the referentiality towards the expressivity. Unlike the political language, the poetic language is no longer controlled by the emitter's interests, no longer aims at convincing the audience, but suggests a reinvention of the verbal sign, a return to the mythical powers of the word, which is no longer resumed at appointing but at creating.

\section{CONCLUSION}

The political language, as instrument of communicating the events from the political field, represents an emphatic symbolic dimension, the linguistic exchanges being susceptible to express, in different ways, the relations among the participants to the communication act, the hierarchies inside the same political group, the affinity towards one ideology or another. Science of the power to decide, the politics used the word in order to express the relations of power, and the word, at its turn, serves to consolidating a position in the relation of power. 
From this perspective, the description of the political language is often done in a pejorative manner, closely related to terms like manipulation and mystification. Aiming at taking and handling power, the political language bears the imprint of its pragmatic anchorage, gaining a distinctive physiognomy among the other types of language. The political doctrine imposes specific discursive manifestations to the speakers, putting under interdiction subjects and expressions which are in contradiction to it. The political language creates connexions among people who share the same ideology and, in the same time, differentiate them from the rest of the community, becoming a distinctive brand for the political group to which the emitter belongs and of the value promoted in its context.

The identity of the political language, as reflection of the ratio between the essence of the human being and the social - political structure of its existence, is built referring to the pragmatic dimension that rules the discursive manifestations from the political field, through the specific phenomenon of reinterpretation, reconstruction of the political referential, according to the emitter's interests. Unlike other types of communication, in which the informative function is a priority, the political community is characterised by dissimulation and persuasion. The political language has a conflict character, permanently referring to the discursive manifestation of the political opponents or the previous discursive manifestations of the same emitter. Despite the closeness to the journalistic language or to the legal language, the political language is defined through specific features, both at the level of the contents approached and at the level of the expression.

\section{Acknowledgement}

This work was published with the support of the ERASMUS MUNDUS Project EMERGE (Erasmus Mundus European Mobility with Neighbouring ReGion in the East), Action 2 - Strand 1 (2009-2013), Grant Agreement no. 2011-2576/001-001-EMA2, (Lot 8: Moldova, Ukraine, Belarus), funded by the European Union.

\section{Biography}

Mihaela MOCANU - is Post-doctoral Researcher at Human Science Research Department of “Alexandru Ioan Cuza" University of Iași, Romania. Since 2012 joint PhD Degree, awarded by the Faculty of Philosophy and Socio-Political Sciences and the Faculty of Computer Science. The author of several articles and studies in scientific journals and a book of political language semiotics. Areas of research: semiotics, philosophy of language, linguistics, semantics, pragmatics and literary hermeneutics.

\section{References}

[1] Chivu, Gheorghe, (1997), Consideraţii asupra limbajului bisericesc actual, Editura Academiei, Bucureşti.

[2] Codoban, Aurel, (2005), Filosofia ca gen literar, Ediţia a II-a, Idea Design\&Print Editură, Cluj Napoca.

[3] Coteanu, Ion, (1973, 1975), Stilistica funcţională a limbii române, 2 vol., Editura Academiei, Bucureşti.

[4] Edelman, M., (1999), Politica şi utilizarea simbolurilor, traduction by Ruxandra Nichita, Polirom, Iaşi.

[5] Habermas, Jurgen, (1983), Cunoaştere şi comunicare, traduction by Andrei Marga, Walter Roth şi Iosif Wolf, Editura Politică, Bucureşti. 
[6] Marga, Delia, (2004), Repere în analiza discursului politic, Editura Fundaţiei pentru Studii Europene, Cluj-Napoca.

[7] Mastacan, Simina, (2004), Discursul implicit al dreptului, Editura Junimea, Iaşi.

[8] Liiceanu, Gabriel, (1992), Cearta cu filozofia. Eseuri, Humanitas, Bucureşti.

[9] Oprea, Ioan, (2001), Curs de filosofia limbii, Editura Universităţii Suceava, Suceava.

[10] Sălăvăstru, Constantin, (2009), Discursul puterii, Editura Tritonic, Bucureşti.

[11] Wald, H., (1983), Ideea vine vorbind, Cartea Românească, București.

[12] Wittgenstein, Ludwig, (1993), Caietul Albastru, traduction by Mircea Flonta, Mircea Dumitru and Adrian-Paul Iliescu, Humanitas, Bucureşti.

[13] Zafiu, Rodica, (2007), Limbaj şi politică, Editura Universităţii din Bucureşti, Bucureşti. 